\title{
THE FREEDOM OF TRAVELLING AND THE ALCHEMIST: HAPPINESS IS WITHIN US
}

\author{
Prakash Thapa, \\ $\mathrm{PhD}$ Scholar, Creative Writing \\ Executive Director, Ridgewater School
}

\begin{abstract}
The protagonist of The Alchemist Santiago longs to travel to fulfill his dreams and likes to be liberated from his status quo of life in essence. He thinks that one can discover the new dimension of life by travelling into the faraway land; this also shows the archetype of nomadic instinct of human beings, for they have always travelled from one place to another in search of prosperity and fulfillment. He desires something new so that he can come out of the conventional pattern of life in general. For him travelling to the unknown brings freedom, wealth and emancipation in life. So he chooses to travel and keeps dreaming.
\end{abstract}

Keywords: travel, freedom, dreams, liberation, desires for unknown

\section{INTRODUCTION}

The Alchemist is a novel of passionate traveller Santiago, who dreams to travel to the faraway places so as to fulfill his needs and find contentment in life. He has deep desire for moving into the unknown, he seems to be discontent to his surroundings and circumstances. So he likes to follow the soul of the universe, the omen of god. He dreams that he has reached the pyramid and finds the hidden treasure. So he meets the women who can interpret his dream. And the woman says, "And dreams are the languages of God. When he speaks in our language, I can interpret what he has said. But if he speaks in the language of the soul, it is only you who can understand ..."(12).

Furthermore, if one desires to achieve his realms, the universe conspires in helping him to fulfill his dreams from every possible dimension. ...It prepares his spirit and his will because there is great truth on this planet: whoever he is, or whatever it is that he does, when he really wants something, it's because that desire originated in the soul of the universe. It's his mission on earth" (21).

Santiago dreams for the unknown, for it has infinite possibilities of movements, prosperities and fulfillments and is guided by the cosmic thought gravity. So he tries to listen to his heart rather than listening to the mind which is rational and creates fear in life.

The Exposures of a Nomad (n.d.) states that The Alchemist is an exciting novel that bursts with optimism; it is the kind of novel that tells you that everything is possible as long as you really want it to happen. That may sound like an oversimplified version of new-age philosophy and mysticism, but as Coelho states "simple things are the most valuable and only wise people appreciate them."

Likewise, it also quotes the Dalai Lama and reveals about how things are predetermined and that they are manifested in human lives. It also says that we are in a time when there are numbers of windows in a house but nothing in the room. It is to this society that Coelho reminds of dreams, of destiny, of courage, of joy, of love, of harmony with the self and of adventure.

Also The Alchemist Analysis (1993) states that for The Alchemist, Coelho adapts four principles from the tale: the personal quest, the awareness of omens, the soul of the world, and the idea of listening to ones heart as a guide. The novel also mentions One Thousand and One Nights when Santiago and the Englishman see many wells, colored tents, and trees in the oasis. The Englishman acknowledges that the view looks like a scene from the classic story.

Moreover, Santiago seems to be wandering in his dreams as if he is a Narcissist, for he is searching his own image in particular. Simon de Beauvoir (1997) states that love and life can be integrated with life and so Santiago is revolving 


\section{International Journal of Engineering Applied Sciences and Technology, 2021 \\ Vol. 6, Issue 4, ISSN No. 2455-2143, Pages 55-59 \\ Published Online August 2021 in IJEAST (http://www.ijeast.com)}

within his own inner journey. So Beauvoir in The Second Sex asserts the similar thought pattern in the psyche of an individual which turns out to be the recurring patterns of inner realities in particular. Santiago is in the existential quest of his own journey of wilderness - the journey of his own choices.

\section{OBJECTIVES}

The objective of this research work is to state that man can find his happiness within; it cannot therefore be searched outside. The material world can give pleasure and sensation momentarily because everything is impermanent Rinpoche (1994). For instance, Santiago, the protagonist of The Alchemist travels towards Egyptian pyramid in search of treasure and contentment but fails in his mission. However, he finds his happiness upon returning his own home, the Andalusian terrain. It is as if: two thousand five hundred years ago the Buddha delivered a remarkable set of teachings. He taught that instead of relying on a god or on materialistic pursuits, one can attain true, permanent happiness by simply examining and working with one's mind (Rinpoche 14).

\section{REVIEW OF LITERATURE}

According to The Alchemist Literary Criticism (n.d.), a dream under a sycamore tree begins an adventure for the young shepherd, Santiago. The dream reveals a treasure waiting to be discovered, but the treasure appears to be in Egypt at the base of a pyramid, and Santiago is living in the Spanish town of Tarifa. What appears, at first, to be a quest for treasure, soon becomes a tale of discovery. Santiago discovers the value of achieving his Personal Legend, the importance of unity and connectedness within nature, and the hope that comes when oneness is reached.

Likewise The Alchemist Literary Criticism further mentions that Paulo Coelho, the author of The Alchemist, introduces the concept of a Personal Legend, and the pursuit and completion of a Personal Legend is the golden thread woven into the engaging storyline. We discover within the story that Personal Legend is the key to living a successful and satisfying life as perfection comes from achieving your Personal Legend.

Santiago eventually realizes this truth after first avoiding the distraction of personal wealth gained through working with a crystal merchant, and the distraction of love found in the unexpected encounter with the beautiful Fatima. While on this journey, he receives assistance from a travelling alchemist, who is an Englishman. While travelling across the Sahara, this Englishman helps Santiago better understand his quest for Personal Legend. In the concluding section of the book, it is revealed to the reader that we are just as important as the actual treasure which Santiago finds upon returning to his Spanish town.

Similarly Kirkus (n.d.) states that the story is about a youth empowered to follow his dream. Santiago is an Andalusian shepherd boy who learns through a dream of a treasure in the Egyptian pyramids. An old man, the king of Salem, the first of various spiritual guides, tells the boy that he has discovered his destiny: to realize one's destiny is a person's only real obligation. So Santiago sells his sheep, sails to Tangier, is tricked out of his money, regains it through hard work, crosses the desert with a caravan, stops at an oasis long enough to fall in love, escapes from warring tribesmen by performing a miracle, reaches the pyramids, and eventually gets both the gold and the girl.

Along the way he meets an Englishman who describes the Soul of the World; the desert woman Fatima, who teaches him the Language of the World; and an alchemist who says, "Listen to your heart." A message clings like ivy to every encounter; everyone, but everyone, has to put in their two cents' worth, from the crystal merchant to the camel driver ('concentrate always on the present; you'll be a happy man').

\section{Dream, Desire and Travel to the Unknown}

It is obvious that Santiago longs to travel to the faraway land to satisfy his desire of fulfilling his heart. Dream, desire and travel are the metaphors of his passionate soul which make him move toward the unknown. He therefore listens to his heart's voice considering that it is indeed the god's own voice which reminds him of his very destiny. So he is tuned to his heart irrespective of his mind's rational disposition. So he always thinks of travelling to Egypt, the unknown land of his dream, so as to find treasure and happiness.

Prakash Thapa (2006) also states that travelling to the unknown gives liberation:

You know silence speaks more than words, and this is in a sense, a 


\section{International Journal of Engineering Applied Sciences and Technology, 2021 \\ Vol. 6, Issue 4, ISSN No. 2455-2143, Pages 55-59 \\ Published Online August 2021 in IJEAST (http://www.ijeast.com)}

way toward freedom: freedom of an individual passion. When I think of walking amidst the mountains, I find a sense of freedom. The moment is beautiful and I start thinking of life: how can I understand life in its entirety, and yet I find, in the mountain trails, an eternal silence, for silence signifies an eternal bliss. That people in most instances come to enjoy the wilderness of the mountains, and free themselves, bringing liberation into their soul: the liberation of the self (19).

And moreover everything on earth is being continuously transformed, because the earth is alive... and it has a soul. We are part of that soul, so we rarely recognize that it is working for us. But in the crystal shop you probably realized that even the glasses were collaborating in your success (75).

The similar thought structure of the inner search is also predominant in Poems of Kabir. Tagore (2002) states that a man is at his home when he is in tune with his inner self. This highlights the integration of the self with the very thoughts of freedom in essence (35). Likewise, Khenchen Thrangu Rinpoche (1994) also states that a man can find eternal peace and the realm of silence when he is "placing the mind" in accordance with his own compassionate thoughts in essence. Rinpoche further calls it a state of relaxation which is how one enters meditation (17).

We can also find the sense of freedom of the mind in J. Krishnamurti (2005) as well, for he says that thought creates the thinker who isolates himself to give himself permanency, for thoughts are always impermanent (60).

\section{Maktub: an Arabic Predeterminism}

So far The Alchemist tries to state the theory of Arabic concept of pre-determinism, for it advocates that everything in the universe is already determined, so that everybody has to undergo the fate according to his predetermined destiny. So The Alchemist's assertion is to some extent pessimistic in its undertone if we compare its advocacy in terms of quantum physics and other sciences.

Contrarily, it is quite clear that the world is not only governed by deterministic thinking but it is also largely governed by the laws of science as well. This theory of determinism is similar to that of the eastern concepts of fate and undying soul, so that man is compelled to believe his destiny rather than the changing theories of science and humanism.

So concerning fate, $\operatorname{Cram}($ n.d.) mentions that "some things are destined to be," a quote from the book Lover Mine by J.R. Ward, and this means that sometimes fate controls our lives and we have no choice in changing our destiny, as some things are made to be, whether we like it or not. In the novel The Alchemist by Paulo Coelho, the protagonist Santiago is pushed by fate out of his comfort zone, to embark on his journey and fulfill his personal legend and experience the marvels of the world (32). His destiny is always controlled by fate, as all his decisions are influenced by fate in one way or another. Fate is the one thing that forces you into uncomfortable situations and brings about the potential within one's self.

Likewise The Alchemist clearly states that Santiago is learning the Language of the World, and everything in the world is beginning to make sense to him even the flight of the hawks. Furthermore, it states that things make more sense when one is in love in essence.

\section{Cosmic Soul and Its Impact}

Regarding the subject of cosmic soul and its impact The Alchemist straightforwardly puts forward its views of Universal Soul that makes impression on all beings. According to Gradesaver (n.d.), one of the fundamental themes of The Alchemist is that our paths are pre-ordained or maktub, in the words of the shopkeeper. The goal of life is to live in harmony with what is ordained for one, or one's Personal Legend; happiness depends upon this harmony.

Moreover, we all once knew, as children, what our Personal Legends were. The main problem is that as humans and adults, we strive to make things more complex than they really are. In the text of The Alchemist, this problem is mirrored by the experience Santiago has with alchemy.

Likewise while travelling through the desert with the Englishman, Santiago reads several books about the secrets of alchemy. The books claim that the original secret of alchemy could be written in a single sentence, but that mankind had made its explanations of that secret so convoluted that they could not be understood by anyone. Santiago rejects this and contends that he can learn everything he needs to know about alchemy through his day-to-day life. This conviction, that one's fate, or Personal Legend, is apparent in any aspect of one's normal life forms one of the most important themes of The Alchemist. 


\section{International Journal of Engineering Applied Sciences and Technology, 2021 \\ Vol. 6, Issue 4, ISSN No. 2455-2143, Pages 55-59 \\ Published Online August 2021 in IJEAST (http://www.ijeast.com)}

When Melchizedek says, "When you want something, all the universe is conspiring to help you achieve it ( Coelho 22)," he means that since it is fate that puts a desire in Santiago's heart, fate won't stop him from achieving it. The problem is focusing one's energy on determining what it is that one really wants. Santiago does this during the last leg of his journey with the alchemist, when he learns from the desert to look inside him and silence his petty fears.

By silencing these fears, he is able to finally see that he is one with the world around him and that his Personal Legend is a harmonious part of that world. This is evinced in a magical fashion when Santiago is able to communicate with the elements, in the climactic scene in which he turns himself into the wind.

Likewise, Thapa (2006) states that beauty is independent to consciousness, and it gives spaces of freedom. Freedom is the way of living, it is liberating, and it gives emancipation from all worldly clinging (253).

\section{Travelling to the Unknown}

That, Santiago is desiring throughout the time, is his longing for the unknown, to the infinite. It advocates at the same time some sorts of spiritual undertones. The universe with its vast expanse is infinite in nature, it is unknown, and yet it controls all lives in the universe, thus generating some kind of special driving force which Santiago calls as the unknown.

For instance, Gradesaver (n.d.) states that the unity of all existence can be traced as a theme through two main aspects of the narrative. First, as Coelho describes it, the Soul of the World unites us all - people, plants, rocks and elements. Second, that there is no significant difference between the different religions of the world. In the narrative of The Alchemist, this unity of humans and the natural world is pointed out several times.

One example is The Alchemist's assertion that even material elements have a Personal Legend. The reason that alchemists can turn any metal into gold is because it is the Personal Legend of that common metal to become gold. The alchemist helps achieve their Personal Legends in much the same way as the alchemist helps Santiago realize his own Legend. This unity with the natural world can also be seen when Santiago converses with the wind, the desert and, finally, the one hand which wrote everything. This, the reader is to understand, is God.

\section{The Castle, Caravan and the Oasis}

Obvious as it is that the castle, caravan and the oasis are the metaphorical representations of dream, desire, travel and hope to certain extent. Since Santiago desires to see new places, cross the deserts, meet new people to bring some change in his life. So the boy is unconventional to the extent that he wants to break the common monotony of life in particular.

$\mathrm{He}$ has dreams. He seems to be creative in life. He is not static. He is a seer. So he longs to travel to the unknown world, cross the desert, observe the caravansary and oasis which is lifegenerating drives for Santiago. This concept is further revealed in Gradersaver as well. For instance, dreams in the sense of "goals" or "aspirations" also constitute a major theme.

Santiago's dream of the treasure provides him with a goal; Santiago resolves to find the treasure, and by his decision to pursue this goal he is able to realize his Personal Legend. Thus, Coelho plays with the dual (and of course linked) meanings of the word "dream", as both visions during slumber and far-reaching objectives.

In this sense, the message of The Alchemist could be described as follows: everyone needs a dream. The vulnerable periods of Santiago's journey are when he has no clearly defined goal. This is true when he finishes working at the crystal shop, as well as when he contemplates staying at the oasis with Fatima. Both times he thinks about desisting, but winds up carrying on unswayed.

Likewise Thapa (2006) also states that one feels free when he is liberated from the old dogma and theories. So, one can really begin his journey of freedom, the journey of the inner self to discover the eternal truth and happiness ( 59).

\section{Happiness Is Within Us}

The main concept of The Alchemist is that happiness comes from within. For instance, Santiago leaves his home, the Andalusian region in search of treasure. But, on the contrary, he loses even things he has. He ultimately returned homeland and under the abandoned church he discovered his treasure. So the essence of living in contentment is within us, it is with everyone else.

So the boy stood up shakily, and looked once more at the pyramids. They seemed to laugh at him, and he laughed back, his heart bursting with joy. Because, now he knew where his treasure was ( Coelho 158).

The boy becomes a traveller of his own desires and Osho (2012) also states that it is something like that of the fourth dimension: travelling into the unknown, thus unfolding the multiple paths of inner dimensions, and this is 


\section{International Journal of Engineering Applied Sciences and Technology, 2021 \\ Vol. 6, Issue 4, ISSN No. 2455-2143, Pages 55-59 \\ Published Online August 2021 in IJEAST (http://www.ijeast.com)}

something very creative dimension of life in particular (254).

So the boy travels in freedom, crossing the barriers of mind and thought patterns thus following his own voice, the voice of freedom. This spirit is much parallel in terms of freedom interpreted by Tagore (2002), for he states that the world has not been broken up into fragments of narrow domestic walls and where the mind is led into ever widening thought and action (Tagore, 35).

So, Santiago finally feels at his home after his journey of inner self into the realm of the unknown. He feels as if he is enlightened to himself.

\section{REFERENCES}

1 Beauvoir, Simon de. The Second Sex. London: Vintage Books, 1997.

2 Coelho Paulo. The Alchemist. Noida: Harper Collins Publications, 2018.

3 "Critique of the Alchemist." Exposures of a Nomad, 2010, www.exposure of a nomad.faustoaarya.wordpresss.com/critiqueof-the alchemist-paulo-coelho. Accessed 10 October 2020.

4 Krishnamurti, J. Commentaries of Living, edited by D. Rajgopal. Chennai: Sudarsan Graphics, 2005.

5 Osho. Osho's Vision on Education, designed and compiled by Swami Anand Vairagya. New Deli: Fusion Books, 2012.

6 Rinpoche, Khenchen Thrangu. The Four Dharmas of Gampopa. Translated by Ken and Katia Holmes. Kalmaian Avenue: Namo Buddha Seminar, 1994.

7 _. The Four Noble Truths. Translated by Ken and Katia Holmes. Kalmia Avenue: Namo Buddha Seminar. Namo Buddha Publications, 1994.

8 Tagore, Rabindranath. Poems of Kabir. New Delhi: Rupa.Co., 2002.

. Gitanjali. Introduction by W.B. Yeats. New Delhi: Indialog Publications Pvt. Ltd., 2002.

9 Thapa, Prakash.. Mountain Incantations. Kathmandu: Silent Himalaya, 2006.

_. Imaginations and Other Essays, unpublished manuscript. manuscript.

Distant Horizons, unpublished

10 The alchemist." Kirkus, www.kirkusviews.com/book-reviews/Paulocoelho/the- alchemist. Accessed 10 October 2020.
11 "The Alchemist Analysis." Endnotes, www.enotes.com/topics/alchemist-paulocoelho/in-depth. Accessed 7 October 2020.

12 "The alchemist themes." Gradesaver, www. gradesaver.com/the-alchemist-coelho-studyguide/themes. Accessed 7 October 2020.

13 "The Importance of Fate in the Alchemist by Paulo Coelho." Cram, www.cram.com/essay/The-importance-offate-in-the-alchemist. Accessed 7 October 2020.

14 "The realization of a dream." The Alchemist Literary www.study.com/academy/lesson/thealchemist-literary-criticism-html. Accessed 10 October 2020. 